\title{
Bat remains (Mammalia, Chiroptera) from the Middle Pleistocene site of Qesem Cave, Israel, with the first Pleistocene record of fruit bats in the Mediterranean region
}

\author{
Ivan Horáček, Lutz Christian Maul, K.T. Smith, Ran Barkai, and Avi Gopher
}

\begin{abstract}
Very few data are available on fossil bats of the Near East, a region of great biogeographic significance for that group in the Western Palaearctic. Here, we report on a collection of fossil bats from the Middle Pleistocene site Qesem Cave, Israel, famous for lithic artifacts, hominin remains and rich vertebrate faunas. We identified five microchiropteran species, viz. Rhinolophus ferrumequinum, R. euryale, R. mehelyi, Miniopterus cf. schreibersii, and Myotis blythii, all typical cave-dwellers common also in extant communities in the region. Their appearance suggests mild conditions with variegated vegetation at the time of deposition. In addition, two tooth fragments, tentatively identified as cf. Rousettus sp., provide the first Pleistocene record of fruit bats beyond the tropics. If these remains pass muster, the Quaternary history of fruit bats in this region could be traced back to the Pleistocene, earlier than previously thought, and then the extant extralimital population of Rousettus aegyptiacus could be seen as a palaeochoric element of the Mediterranean biota. In general, the Pleistocene record of bats in the Levant (including Qesem) is characterized by the absence of the Ethiopian elements that dominate the extant Levantine fauna, while the vast majority of the fossil bat forms are elements of the Palaearctic clades.
\end{abstract}

Ivan Horáček. Department of Zoology, Charles University, Vinicna 7, CZ 12844 Praha, Czech Republic, ivan.horacek@natur.cuni.cz

Lutz Christian Maul. Research Station of Quaternary Palaeontology, Senckenberg Research Institute and Natural History Museum, Am Jakobskirchhof 4, 99423 Weimar, Germany, Imaul@senckenberg.de K.T. Smith. Department of Palaeoanthropology and Messel Research, Senckenberg Research Institute and Natural History Museum, Senckenberganlage 25, 60325 Frankfurt, ksmith@senckenberg.de Ran Barkai. Department of Archaeology, Tel Aviv University, Ramat Aviv, Tel Aviv 69978, Israel, barkaran@post.tau.ac.il

Avi Gopher. Department of Archaeology, Tel Aviv University, Ramat Aviv, Tel Aviv 69978, Israel, agopher@post.tau.ac.il 
Keywords: Middle Pleistocene; Israel; Chiroptera; taxonomy; taphonomy; biogeography; Rousettus

\section{INTRODUCTION}

The Mediterranean is often regarded as one of the most complex and diversified regions of the world from an environmental and biogeographical point of view (Quézel, 1985; Blondel and Aronson, 1999; Médail and Diadema, 2009; Blondel et al., 2010). This holds true also for mammals: the region is inhabited by 319 species (Temple and Cuttelod, 2009) including the vast majority of the 253 European species (Aulagnier et al., 2009). Compared to the Western Mediterranean, characterized by predominant effects of palaeoendemism (Ibanez et al., 2006), the Eastern Mediterranean, including Middle East, represents a nexus in West Palaearctic biotic history. Its extant fauna comprises palaeoendemic populations of European elements as well as elements of Afro-eremial, Irano-Sindian, or Turanian origin (Horáček et al., 2000; Blondel, 2009). The unique features of that region may be elucidated by studying the history of faunal interchange directly in the local fossil record (Tchernov, 1992). The present paper is a step in this direction, focusing on bats, a group that, in regards to its species richness and dispersal capabilities, might serve a suitable model system for such analyses.

The region of Eastern Mediterranean is currently inhabited by 64 bat species; 60 of these reach the margin of their distribution there. Characteristics of the Mediterranean bat communities were found to be the most significant contributor to structural diversity in Palaearctic bat faunas (Horáček et al., 2000). The essential role of the Eastern Mediterranean in emergence of phylogeographic diversity has been repeatedly confirmed (e.g., Hulva et al., 2004; Juste et al., 2004; Bilgin et al., 2006; Hulva et al., 2010; Hulva et al., 2012; Salicini et al., 2012). Yet, the history of extant genotypes inferred from phylogeographic analyses is not always a history of the species. Furthermore, the inferential nature of molecular phylogeography does not dispose it to provide any direct information on past distributions, on the role of species in extant communities, on the contextual factors determining the pathways of their actual history, the history of community rearrangements, the course of dispersal and extinction events or on local variation in faunal history and phenotypic rearrangements. Such information is available only from fossil record. Thus, to reconstruct the path- ways producing current diversity of bat fauna in the Eastern Mediterranean means first to turn attention to the fossil record.

In contrast to Europe, where a very rich fossil record of small mammals provides a detailed information on faunogenetic history of the Late Cenozoic, the available data from the Near East are still rather scarce. Intensive archaeological investigations undertaken in the Levant in recent decades, particularly in Israel, fill part of the gap with detailed information from a series of sedimentary and faunal sequences including the Middle and Late Pleistocene (Tchernov, 1992; Frumkin et al., 2011). However, most information on the Pleistocene history of small mammals in the Levant relates to rodents, whereas for other groups, including bats, data are very scarce. Partly because they are not considered to be very significant from an archaeological viewpoint, bats have not often been treated in detail, as can be seen in the following short overview.

The Early Pleistocene bat material from the site of Ubeidiyah in Israel is referred to as Microchiroptera indet. (Haas, 1966). Middle Pleistocene bat remains were recovered during the large scale excavations at Tabun Cave, Mt. Carmel (Bate, 1937). The species identified included Megaderma watwat (in layer F - late Acheulean), Myotis cf. baranensis, Rhinolophus sp. (in layer $\mathrm{Ed}$ Acheulo-Yabrudian), and Myotis cf. baranensis (in layer D - Mousterian). New excavations at Tabun Cave (Goldberg et al., 1973) provided additional bat remains, under investigation by B.W. Woloszyn (Cracow) (R. Rabinovich pers. comm.). This assemblage includes several bat species, dominated by Rhinolophus ferrumequinum, Myotis blythii, and Miniopterus sp. (pers. obs., I. Horáček in the Hebrew University collection, Jerusalem). At the late Middle Pleistocene (late Lower Palaeolithic) site of Oum-Qatafa, Haas (1951) identified three mandibles of Rhinolophus, referred to as $R$. ferrumequinum, $R$. euryale, and a Rhinolophus species intermediate in size. Haas (1967, and a list in Boutié, 1979) also reported a bat assemblage from the Mousterian site Geula B (Mt. Carmel) composed of Rhinolophus ferrumequinum, $R$. hipposideros, R. blasii, R. euryale, $R$. sp., Myotis sp. (small) and Miniopterus sp. In a review of the Mousterian sites of the Levant Boutie (1979) quoted a record of Tadarida teniotis and Chiroptera 


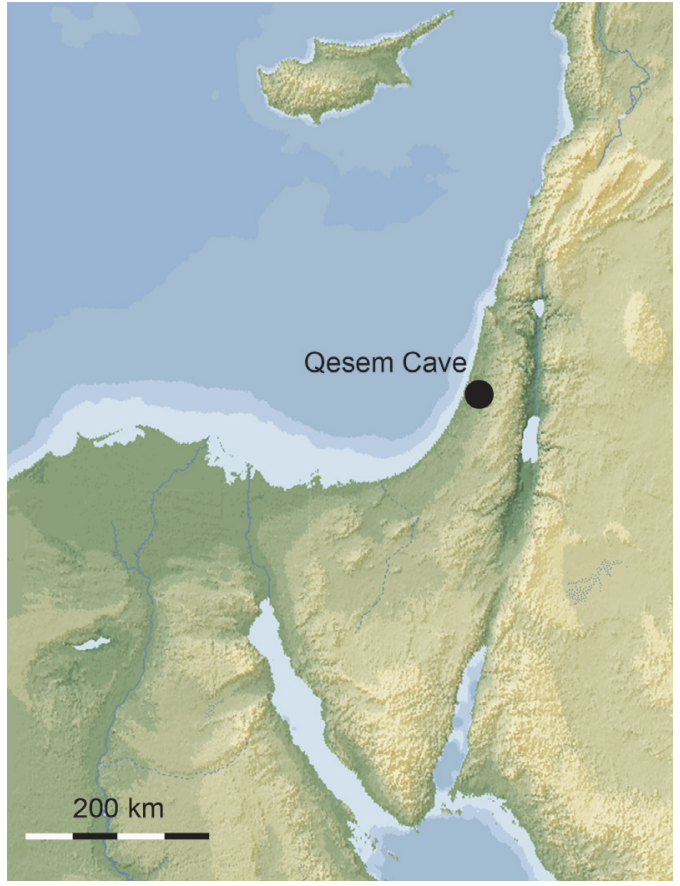

FIGURE 1. Location of the Middle Pleistocene Qesem Cave.

indet. (identified by G. Haas) from the site of Shoubbabiq (Shovakh) Cave. Unpublished osteological and dental material from the Late Mousterian site of Kebara deposited in collections of the Hebrew University, Jerusalem, includes remains of at least three species: Rhinolophus cf. mehelyi, Miniopterus sp. and Myotis cf. blythii. Tchernov (1984) reported numerous remains of bats (which "still require identification») from the Historical Period (layers 2-5) of Sefunim Cave at Mt. Carmel including Rousettus aegyptiacus, which was abundant also in the Neolithic Period (layers 6-7). Unidentified bat remains were excavated from the same site in the Upper Palaeolithic layers 8a-8, and in the Aurignacian layers 9-11 (op. cit.). To sum up, the currently available fossil bat material recorded from Israel is still not very rich.

The recent excavations of a multi-layered Middle Pleistocene deposit at Qesem Cave provided a particularly rich collection of small vertebrates (Maul et al., 2011) amounting to thousands of identifiable specimens in a well-dated context, among them bats. As in the aforementioned Pleistocene sites, at Qesem the amount of bat material is also unfortunately limited. However, regarding the scarcity of fossil record in this region, the new data improve our knowledge about the history of Levantine bat faunas.

\section{QESEM CAVE SITE}

The site of Qesem Cave $\left(32.102142^{\circ} \mathrm{N}\right.$, $34.986627^{\circ} \mathrm{E}, 90 \mathrm{~m}$ a.s.l.) is located some $12 \mathrm{~km}$ east of the present day Mediterranean coast, on the moderate western slopes of the Samarian hills (Figure 1). Presently, the area is situated within the Mediterranean climatic zone with a mean annual precipitation of $500-600 \mathrm{~mm}$. The cave is a sediment-filled karstic chamber cave some $20 \times 15 \mathrm{~m}$ in size and ca. $10-12 \mathrm{~m}$ high. It is part of a larger karstic system within the limestone of the B'ina Formation (Turonian, Late Cretaceous). By the Middle Pleistocene, the cave had been breached by natural erosion allowing the entry of hominins and anthropogenic sediment deposition (Frumkin et al., 2009).

All layers of the $9.5 \mathrm{~m}$ stratigraphic sequence of Qesem Cave were securely assigned to the Acheulo-Yabrudian Cultural Complex - AYCC (late Lower Palaeolithic, Middle Pleistocene) (Barkai et al., 2003; Gopher et al., 2005; Gopher et al., 2010; Barkai and Gopher, 2011). The Amudian industry of the AYCC is dominant throughout the stratigraphic sequence and is characterized by systematic blade production and a major component of shaped blades and Naturally Backed Knives (Barkai et al., 2005; Gopher et al., 2005; Shimelmitz et al., 2011). Amudian blades were mostly used on soft tissues for cutting, butchering, and defleshing and were practically conceived as disposable tools, cut and throw-away implements (Lemorini et al., 2006). Recently excavated areas in Qesem Cave revealed the presence of the Yabrudian industry of the AYCC (Barkai et al., 2009; Barkai and Gopher, 2011).

To date, eight hominin teeth have been found in the cave. Their morphometric analysis and a wide-ranging comparative study show that the teeth most closely resemble the Skhul-Qafzeh samples of the Middle Palaeolithic Levant while a Homo erectus assignment is clearly not tenable (Hershkovitz et al., 2011). This is of great importance considering their Middle Pleistocene age (420-200 ka) and may, conjoined with the cultural transformations demonstrated at Qesem Cave, point to the appearance of a new hominin lineage in the Levant some 400 ka (Ben-Dor et al., 2011). Moreover, the macrofaunal remains of Qesem Cave comprise thousands of large vertebrate bones, on which cut marks and signs of burning are frequently observed (Stiner et al., 2009, 2011).

Microvertebrate bone concentrations were found first near-by the eastern cave wall and later another, earlier, concentration was uncovered far- 


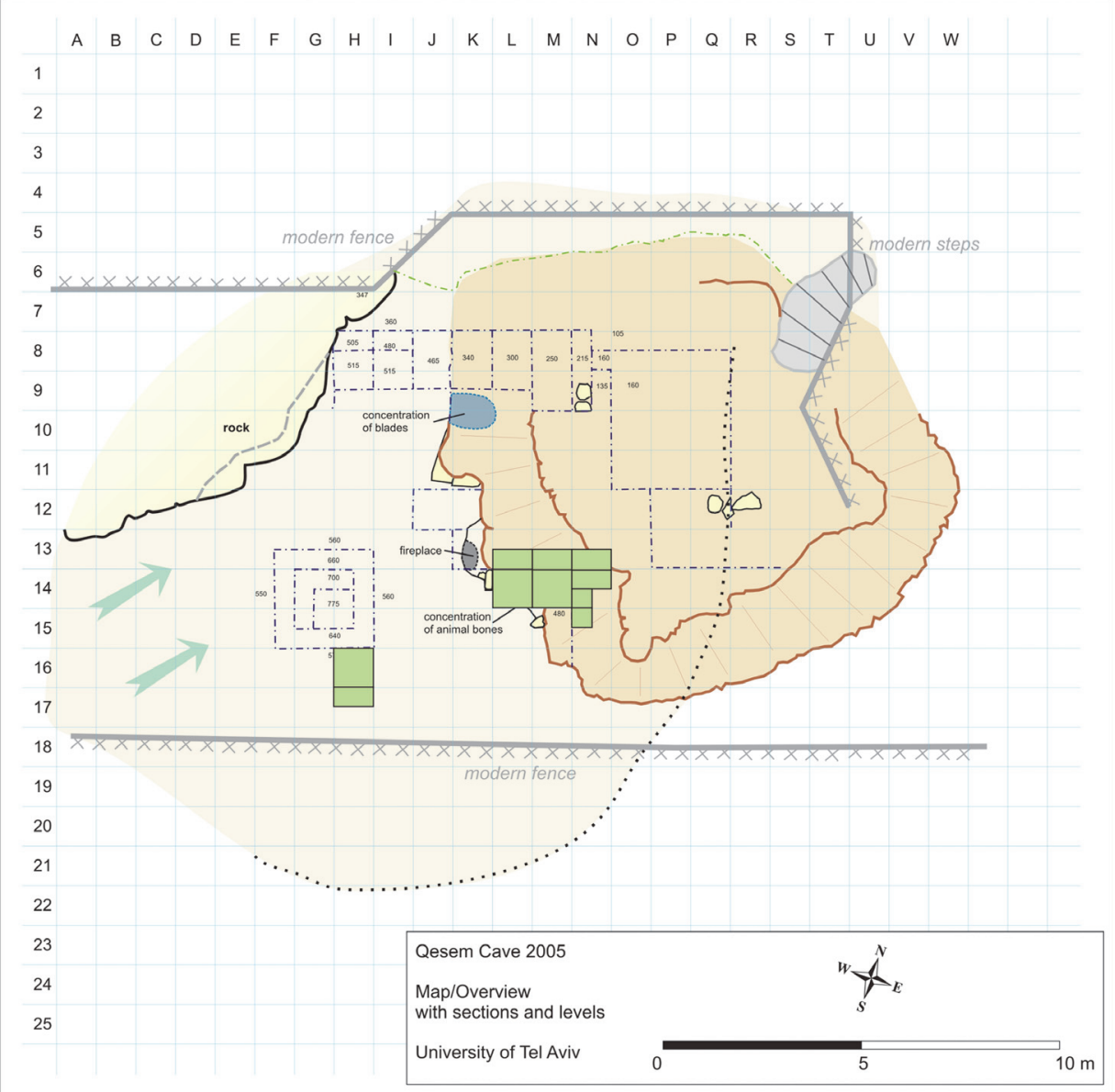

FIGURE 2. Squares of the excavation area of the Middle Pleistocene Qesem Cave with concentration (green areas) of microvertebrate fossils.

ther to the west. Preliminary investigations of the small vertebrate remains (material of excavation seasons between 2006 and 2008) from the first concentration (squares L-N/13-15, see Figure 2) enabled the identification of some $50 \%$ of 10,000 specimens to the generic and some hundreds to the species level. The assemblage included a variety of small reptile and mammal taxa (Maul et al., 2011). Thus far there is no evidence that the fauna of the cave consists of taxa other than those occurring in Israel today. However, the currently available material from the three excavation seasons of 2009 to 2011 (some 15,000 remains identified at least to the generic level) including finds from both the above mentioned concentration (including the newly found concentration in squares $\mathrm{H} / 16-17$ ) provides, at least for the vole population (Microtus guentheri), clear morphometric differences compared to the recent members of the species.

The ecological preferences of the nearest living relatives of the recorded microvertebrate taxa allowed inference of a palaeoenvironment with a mosaic of open and woodland habitats. However, comparing the lower with the upper levels of the microfauna-bearing horizon of squares L-N/13-15, a slight shift towards more wooded conditions might be discernible (Maul et al., 2011). Radiometric dating gives an estimated age range for the fossiliferous sediments of c. 420-200 ka (Gopher et al., 2010), while the microvertebrate-bearing strata are clearly earlier than 250 ka (Mercier et al., 2013).

\section{MATERIAL AND METHOD}

The material surveyed in the present paper was obtained in the frame of detailed multi-disciplinary studies of the site conducted since 2004. The sediment samples taken in the field were screen-washed with $0.8 \mathrm{~mm}$ mesh size for microvertebrates (Maul et al., 2011). All bat remains originate from the two microvertebrate accumulations in squares L-N/13-15 and $\mathrm{H} / 16-17$ 
(Figure 2). Morphological terms, including abbreviations for particular dental elements, as well as measurements follow the standard convention as surveyed by Woloszyn (1987) and Sevilla (1988). The minimum number of individuals is calculated from the most abundant bone or tooth from either the left or right side of the animal. All measurements are given in $\mathrm{mm}$. Abbreviations: I, C, P, M, i, $c, p, m$ - upper (in upper case) and lower (in lower case) incisors, canine, premolar, and molar teeth, $\mathrm{crH}$ - coronoid height (height of ramus mandibulae), $\mathrm{H}$ - height, $\mathrm{L}$ - length, $\mathrm{md}$ - mandible, $\mathrm{MNI}$ minimum number of individuals, $\mathrm{tl}$ - talonid, $\mathrm{tr}-\mathrm{tri}-$ gonid, $\mathrm{W}$ - width. The abbreviations in the catalogue numbers denote Tel Aviv University (TAU), Qesem Cave (QC), and Chiroptera (CHIR) followed by consecutive numbered specimens. Geographic setting of the region, scheme of the Mediterranean vegetation zones and related terms are mostly after Blondel and Aronson (1999), Dov Por and Dimentman (2006), and Allen (2009). The entire fossil material mentioned in this paper will be stored in the Tel Aviv University. During the investigation it is temporarily deposited at the Senckenberg Research Station of Quaternary Palaeontology in Weimar.

\section{SYSTEMATIC PALAEONTOLOGY}

Order CHIROPTERA Blumenbach, 1779

Family RHINOLOPHIDAE Gray, 1825

Genus RHINOLOPHUS Lacépède, 1799

Rhinolophus ferrumequinum (Schreber, 1774)

Figure 3.13-24

Material. Four cochleae (TAU-QC/CHIR-08, TAUQC/CHIR-09, TAU-QC/CHIR-38, TAU-QC/CHIR50: width $=3.62,3.72,4.00,3.90$ ), seven upper canines (TAU-QC/CHIR-10, TAU-QC/CHIR-17, TAU-QC/CHIR-22, TAU-QC/CHIR-31b, TAU-QC/ CHIR-34a, TAU-QC/CHIR-34b, TAU-QC/CHIR-45: width $\mathrm{x}$ height $=2.47 \times 4.05,2.19 \times$ ?, $2.34 \times 4.41$, $2.51 \times 4.30,2.48 \times 3.90,2.42 \times 4.51,2.57 \times 4.14)$, $1 \mathrm{c} 1$ (TAU-QC/CHIR-11: $1.18 \times 3.02$ ), eight mandible fragments (TAU-QC/CHIR-12: Lmd 17.69, im3 10.63, c-m3 10.17, p4-m3 8.30, m1-m3 7.03, m1-m2 4.73, m2-m3 4.70, p4-m1 2.89, c-p4 3.10, crH 4.51, symphysis? x 1.00, mdH 2.30, m1L 2.45, $\mathrm{m} 1 \mathrm{trL} 1.48, \mathrm{~m} 1 \mathrm{trW} 1.23, \mathrm{~m} 1 \mathrm{tIW} 1.50, \mathrm{~m} 2 \mathrm{~L} 2.45$, m2trL 1.39, m2trW 1.38, m2tIW 1.58, m3L 2.25, m3trL 1.10, m3trW 1.42, m3tIW 1.27, TAU-QC/ CHIR-16: m2-m3 4.39, m3L 2.13, m3trL 1.05, m3trW 1.14, m3tIW 1.13, TAU-QC/CHIR-24: m1L 2.40, m1trL 1.23, m1trW 1.24, m1tIW 1.40, TAUQC/CHIR-26: m1-m3 7.22, m1-m2 4.92, m2-m3 4.68, mdH 2.15, m1L 2.34, m1trL 1.40, m1trW
1.45, m1tIW 1.65, m2L 2.49, m2trL 1.42, m2trW 1.46, m2tIW 1.71, m3L 2.22, m3trL 1.16, m3trW 1.34, m3tIW 1.34, TAU-QC/CHIR-27: m3L 2.27, m3trL 1.18, m3trW 1.38, m3tIW 1.22, TAU-QC/ CHIR-28b: m1tr, TAU-QC/CHIR-46: m2-m3 4.66, $\mathrm{crH} 4.77, \mathrm{mdH} 2.75, \mathrm{~m} 2 \mathrm{~L} 2.36, \mathrm{~m} 2 \mathrm{trL} 1.45, \mathrm{~m} 2 \mathrm{trW}$ 1.47, m2tIW 1.54, m3L 2.24, m3trL 1.23, m3trW 1.33, m3tIW 1.19, TAU-QC/CHIR-47: m1-m2 4.73, $\mathrm{mdH} 2.49, \mathrm{~m} 1 \mathrm{~L} 2.30, \mathrm{~m} 1 \mathrm{trL}$ 1.39, m1trW 1.31, m1tIW 1.32, m2L 2.28, m2trL 1.48, m2trW 1.47, m2tIW 1.35, three humerus distal epiphyses TAUQC/CHIR-05: ephipW 5.35, trochW 3.40, diapW 1.71, TAU-QC/CHIR-30: ephipW 5.38, trochW 3.50, diapW 1.61, TAU-QC/CHIR-42: ephipW 5.50, trochW 3.54, diapW 1.65, one humerus proximal epiphysis TAU-QC/CHIR-39: diapW 1.62, one radius fragment (TAU-QC/CHIR-25 b), one tibia fragment (TAU-QC/CHIR-14a), five metacarpal fragments (TAU-QC/CHIR-6, TAU-QC/CHIR-14b, TAU-QC/CHIR-15, TAU-QC/CHIR-32, TAU-QC/ CHIR-41). MNI=7.

Remarks. All morphological details in the above listed specimens correspond to the state characterizing bats of Rhinolophus ferrumequinum group (i.e., $R$. ferrumequinum s. str. and/or closely related forms of uncertain taxonomic rank) - the clade which predominates the Late Cenozoic fossil record throughout the Western Palaearctic. The extant form inhabits an extremely large geographical range from England and Morocco to Southeast China and Japan. The current molecular (mitochondrial and microsatellite) data (Flanders et al., 2009) demonstrate that, in spite of considerable phenotype variation, all extant populations belong to the same clade split into a western and an eastern group by a shallow divergence (about $5 \%$ in ND2). Also, the genetic distances between the west European and Near Eastern populations are very shallow (1.2\% in ND2), which suggests a divergence time at around 300 ka (Bilgin, 2011). Nevertheless, a significant cline in body size, with enlargement from Northwestern Europe to Southeastern Europe and the East Mediterranean, has been convincingly demonstrated (Kryštufek, 1993; De Paz, 1995). This trend further continues to Iran and the Near East, including the Levant (Špoutil, 2003; Benda et al., 2006). It seems that it terminates just at the southernmost Eastern Mediterranean populations of the species in Israel and Jordan where skull dimensions represent maximum values of the species variation range (Mendelssohn and Yom-Tov, 1999; Benda et al., 2010).

Worth mentioning is that in metric characteristics, the Qesem Cave specimens exceed in most 


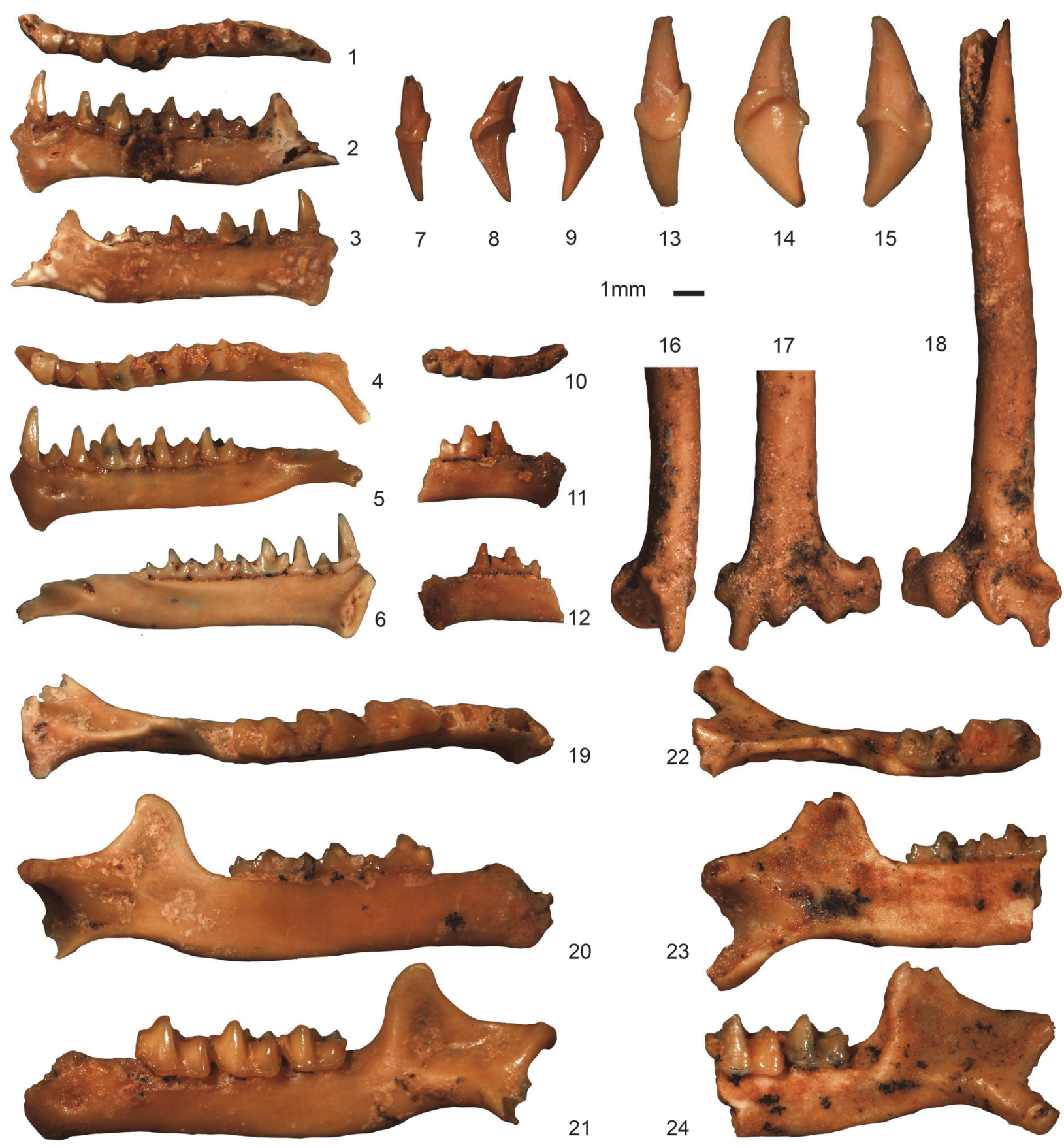

FIGURE 3. Remains of (3.1-6) Rhinolophus mehelyi Matschie, 1901, (3.7-12) Rhinolophus euryale Blasius, 1853, and (3.13-24) Rhinolophus ferrumequinum (Schreber, 1774) from the Middle Pleistocene Qesem Cave: (3.1-3) TAUQC/CHIR-12b, left mandibular fragment, occlusal, buccal, lingual view; (3.4-6) TAU-QC/CHIR-25, left mandibular fragment, occlusal, buccal, lingual view; (3.7-9) TAU-QC/CHIR-37, right upper canine, mesial, lingual, buccal view; (3.10-12) TAU-QC/CHIR-03, right mandibular fragment, occlusal, buccal, lingual view; (3.13-15) TAU-QC/CHIR-10, right upper canine, mesial, lingual, buccal view; (3.16-18), distal epiphysis of right humerus, TAU-QC/CHIR-05, internal, posterior, external view; (3.19-21) TAU-QC/CHIR-12a and (3.22-24) TAU-QC/CHIR-46, left mandibular fragments, occlusal, lingual, buccal view; 
instances the variation limits of extant populations of the species including those from Jordan and Israel (cf. Kryštufek, 1993; Benda et al., 2006; Benda et al., 2010). The same fact was stressed by Bate (1937) for a specimen of Rhinolophus sp. from Tabun Ed, i.e., a layer corresponding in age to Qesem Cave (Frumkin et al., 2011). This seems to corroborate that clinal size differences of this species were already established by the Middle Pleistocene and influenced the evolutionary history of the clade in that region. In the Levant, the extant range of $R$. ferrumequinum is confined to the thermomediterranean zone (in the sense of Blondel and Aronson, 1999; Allen, 2009) in the Galilee, northwest Judea and along the Jordan river, while the arid habitats in the rift zone along the Dead Sea are inhabited by the northernmost populations of its African sister species Rhinolophus clivosus, which differs in its distinctly smaller dimensions (yet significantly larger than in R. mehelyi). In contrast to the regular occurrence of $R$. ferrumequinum s. str., the absence of $R$. clivosus in the Levantine fossil record is noteworthy.

Rhinolophus euryale Blasius, 1853

Figure 3.7-12

Material. Upper canine (TAU-QC/CHIR-37: width 1.61, height 2.97), mandible fragment (TAU-QC/ CHIR-03: c-m1 (3.49, p4-m1 2.39, mdH 1.44, cL (0.59), cW (0.38), p2L (0.35), p3L 0.17, p3W 0.13, p4L 0.85, p4W 0.73, m1L 1.60, m1trL 0.84, m1trW $0.76, \mathrm{~m} 1 \mathrm{tIW} 0.92 . \mathrm{MNI}=1$.

Remarks. The above listed elements belong clearly to a medium-sized form of Rhinolophus. Their metrical characteristics are below the lower limits of variation in $R$. ferrumequinum, $R$. clivosus and $R$. mehelyi, and above the upper limits of variation in the $R$. hipposideros group (from which they differ by distinctly more robust dentition and mandible modelation). In the extant fauna three species may be considered, $R$. euryale and $R$. mehelyi are true Mediterranean elements and are more or less restricted to that region, whereas $R$. blasii is an Ethiopian element which reaches the northern margin of its distribution range in the Eastern Mediterranean. $R$. blasii and $R$. euryale are almost identical in size, and their discrimination is traditionally difficult. Besides the shape of the braincase, they differ in the relative size of $\mathrm{p} 2$ and $\mathrm{p} 4$. The PR ratio comparing the crown occlusal square of $\mathrm{p} 2 / \mathrm{p} 4$ size was confirmed as a reliable discriminating criterion (cf. Popov and Ivanova, 2002; Benda et al., 2006). The Qesem specimen TAUQC/CHIR-03 exhibits a reduced size of $p 2$ and relatively less compressed premolar row which corre- sponds to the state in $R$. euryale. The p3 is relatively large and p2 and p4 were most probably not in contact. Besides smaller dimension this character distinguishes $R$. euryale from $R$. mehelyi where p3 is quite minute and completely displaced from the tooth row.

All the mentioned species are strict cavedwellers and highly social sometimes forming very large colonies throughout the year. In contrast to $R$. blasii, $R$. euryale has appeared in the European fossil record since the early Pliocene (e.g., Muselievo, see Popov, 2004), supposedly as a descendant of the European Late Miocene $R$. lissiensis Mein, 1965. It was recorded in about 30 Pliocene and Early Pleistocene sites in Spain, France, Italy, Hungary, Austria, and Slovakia, yet nowhere in large numbers. At about a half of these sites it was found syntopically with $R$. mehelyi, as is the case at Qesem. $R$. euryale is reported also from the Mousterian site Geula B (Haas, 1967).

\section{Rhinolophus mehelyi Matschie, 1901 \\ Figure 3.1-6}

Material. Upper canine (TAU-QC/CHIR-33: width $\mathrm{x}$ height $=1.90 \times 3.68)$, three mandible fragments (TAU-QC/CHIR-12b: i-m3 (8.09, c-m3 7.54, p4-m3 6.03, m1-m3 5.20, m1-m2 3.61, p4-m1 2.90, c-m1 4.25 , symphysis $2.45 \times 0.63, \mathrm{crH} 2.68, \mathrm{mdH} 1.70$, cL 0.93, cW 1.07, cH 2.07, p2L 0.76, p2W 0.66, p4L 0.97, p4w 0.99, m1L 1.87, m1trL 1.22, m1trW 1.03, m1tIW 1.13, m2L 1.74, m2trL 0.98, m2trW $0.98, \mathrm{~m} 2 \mathrm{tIW}$ 1.11, m3L 1.53, m3trL 0.81, m3trW 1.00, m3tIW 0.89, PR $=0.522$, TAU-QC/CHIR-23: m1-m3 (4.79), m1-m2 (3.29, m2L (1.75, m2tIW 1.25, 25a: Lmd (11.50), i-m3 (8.25, c-m3 7.45, p4m3 6.05, m1-m3 5.16, m1-m2 3.67, c-m1 4.21, p4m1 2.75, c-p4 2.37, symphysis $2.37 \times 0.77, \mathrm{mdH}$ 1.66, cL 0.93, cW 1.14, cH 2.2ř, p2L 0.72, p2W 0.75, p4L 0.95, p4W 0.98, m1L 1.95, m1trW 1.11, $\mathrm{m} 1 \mathrm{tIW} 1.11, \mathrm{~m} 2 \mathrm{~L} 1.72, \mathrm{~m} 2 \mathrm{trW}$ 1.04, m2tIW 1.14, $\mathrm{m} 3 \mathrm{~L} 1.57, \mathrm{~m} 3 \mathrm{trW} 1.02, \mathrm{~m} 3 \mathrm{tIW} 0.95$, three radius proximal epiphysis fragments (TAU-QC/CHIR-13a width = 2.86, TAU-QC/CHIR-21a, TAU-QC/CHIR21b), one femur fragment (TAU-QC/CHIR-49), one metacarpal fragment (TAU-QC/CHIR-21c).

Remarks. Assignment of the above mentioned elements to $R$. mehelyi $(\mathrm{MNI}=3$ ) is based essentially on metrical characteristics (just in between the ranges of variation of $R$. ferrumequinum-clivosus and $R$. euryale-blasii, respectively) and structure of the dentition, which is somewhat more robust than that in $R$. euryale and $R$. blasii. The present material also differs in having a more reduced and bucally displaced p3 (and thus p2 and p4 are in direct contact). $R$. mehelyi is a true Mediterranean 
element, which recently - in contrast to the preceding species - does not appear beyond the limits of the Mediterranean proper (Gaisler, 2001). Yet this was not always the case, e.g., in the period along the MN17/Q1 boundary (end of Gelasian) it is recorded in seven sites in the Panonnian Basin in Hungary and Austria (Jánossy, 1996; Sapper, 1997). It is also reported from MN14 site Podlesice in Poland (Woloszyn, 1987). R. neglectus (Heller, 1936) appearing in three MN15-16 sites of Germany, Poland, and Hungary is considered to be closely related to $R$. mehelyi (cf. Woloszyn, 1987). Late Pliocene and Early Pleistocene records of $R$. neglectus are also available from nine localities in the Mediterranean region (Spain, Italy, Bulgaria Sevilla et al., 1991; Popov, 2004; Tata and Kotsakis, 2005; Agustí et al., 2011). In contrast to the Mediterranean Middle and Late Pleistocene records, the Pliocene and Early Pleistocene specimens of $R$. mehelyi are slightly larger than the extant form and were often co-identified with the form described from Ghar Dalam, Early Pleistocene of Malta, as $R$. mehelyi birzebuggensis Storch, 1974. However, all Qesem specimens fall in the range of the extant species, including the populations of the Levant, and are smaller than $R$. $m$. birzebuggensis (c-m3L $=8.0 \mathrm{~mm}, \mathrm{~m} 1 \mathrm{~L}>2.0$ $\mathrm{mm}$ - cf. Storch, 1974). It should be noted that the type material of $R$. euryale judaicus (Andersen et Matschie, 1904) (type loc. Jerusalem) (nec. R. e. judaicus sensu Mendelssohn and Yom-Tov, 1999) was synonymized with $R$. mehelyi (cf. Kock, in litt. and Benda et al., 2006).

Although recently $R$. mehelyi is perhaps the rarest species of Rhinolophus in the Mediterranean region, its fossil record is obviously relatively rich, even more abundant than in the other two mediumsized forms of Rhinolophus. It cannot be excluded that the recently described Pliocene $R$. maghrebensis (Gunnell et al., 2011) from MN16 Ahl al Oughlam, Morocco also belongs to the clade of $R$. mehelyi-euryale, which would suggest a Pliocene radiation of that group in the inner Mediterranean.

Family MINIOPTERIDAE Dobson, 1875

Genus MINIOPTERUS Bonaparte, 1837

Miniopterus cf. schreibersii (Kuhl, 1817)

Figure 4.1-9

Material. Two maxillar fragments (TAU-QC/CHIR07b: P4-M3 4.64, M1-M3 3.69, M1-M2 2.97, P4L 1.38, P4W 1.44, M1L 1.56, M1W1 1.71, M1W2 1.98, M2L 1.56, M2W1 1.86, M2W2 1.94, M3L 0.85, M3W 1.80, TAU-QC/CHIR-35: P4-M3 4.21), M1-M3 3.42), M1-M2 2.89, P4-M1 2.60, P2L 0.87, P2W 1.06, P4L 1.05, P4W 1.60, M1L 1.54, M1W1
1.81, M1W2 2.05, M2L 1.45, M2W1 1.89, M2W2 1.92), seven mandible fragments (TAU-QC/CHIR01: c-p4 (2.06, p4L 0.66, p4W 0.64, TAU-QC/ CHIR-04: m1-m3 4.14), m1-m2 2.93, crH 2.55, $\mathrm{mdH}$ 1.30, m1L 1.56, m1trL 0.80, m1trW 0.87, m1tIW 1.03, m2L 1.43, m2trL 0.77, m2trW 0.91, m2tIW 0.93, 07a: i-m3 (7.88, c-m3 (6.80, p4-m3 (5.05, m1-m3 4.25, c-p4 2.82, p2-p3 1.20, symphysis $2.25 \times 0.76, \mathrm{mdH} 1.64, \mathrm{cL}(0.73), \mathrm{cW}(0.72)$, p2L 0.65, p2W 0.69, p3L 0.59, p3W 0.72, p4L 0.88, p4W 0.89, m1L 1.54, m1trL 0.77, m1trW 1.07, m1tIW 1.23, m2L 1.40, m2trL 0.68, m2trW 1.06, m2tIW 1.07, m3L 1.32, m3trL 0.64, m3trW 0.92, m3tIW 0.76, 18: m2L (1.38), m2trW 0.85, 20: mdH 1.70, TAU-QC/CHIR-28a: m2L 1.44, m2trL 0.66, m2trW 0.91, m2tIW 1.00, TAU-QC/CHIR-48: Lmd (10.80, i-m3 (7.00, c-m3 (6.18, p4-m3 4.61, m1-m3 3.90, c-p4 (2.43, p2-p3 (0.96), crH 2.59, symphysis $(1.85 \times 0.82, \mathrm{mdH} 1.52, \mathrm{p} 3 \mathrm{~L} 0.49$, p3W 0.59, p4L 0.76, p4W 0.81, m1L 1.34, m1trW 0.85, m1tIW $0.94, \mathrm{~m} 2 \mathrm{~L} 1.31, \mathrm{~m} 2 \mathrm{trW}$ 0.91, m2tIW 0.92, m3L 1.25, m3trW 0.81, m3tIW 0.72. MNI=6.

Remarks. Except for two fragments lacking clear discriminating characters (TAU-QC/CHIR-18, TAUQC/CHIR-20), the assignment of all the above listed items to Miniopterus is unambiguous. Miniopterus is characterized by a specific arrangement of upper dentition, with a large P2, rounded in section, talon-like distal extensions of palatal cingulum at upper molars, nyctalodont lower molars, large p3 with two roots, conspicuously developed angulus mandibulae, low processus coronoideus with horizontal incisura sigmoidea, etc. Some of these characters are unique among vespertilionoid bats and support a separate family status of the genus (Mein and Tupinier, 1977; Miller-Butterworth et al., 2005).

The species identity of the fossil material is uncertain, since recent molecular analyses (MillerButterworth et al., 2005; Bilgin et al., 2006; Furman et al., 2009) demonstrated that the extant Miniopterus schreibersii (Kuhl, 1817), which our material clearly resembles, actually represents a complex of cryptic species, two of which, M. schreibersii (Kuhl, 1817) and M. pallidus Thomas, 1907, occur in the Eastern Mediterranean. Except for a narrow zone of sympatry in Eastern Anatolia and Hatay their ranges are allopatric. The northern Levant and Syria (supposedly also most of Israel) are inhabited by $M$. schreibersii while Iran, Jordan and other regions of the Near East are inhabited by M. pallidus (Benda et al., 2010; Šrámek, 2010; Šrámek et al., 2013) which is obviously an African element closely related to the $M$. natalensis from South 


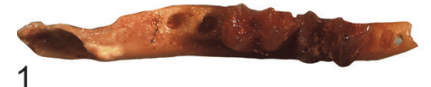

1
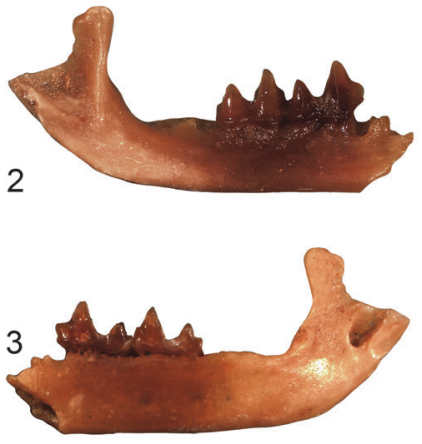

4
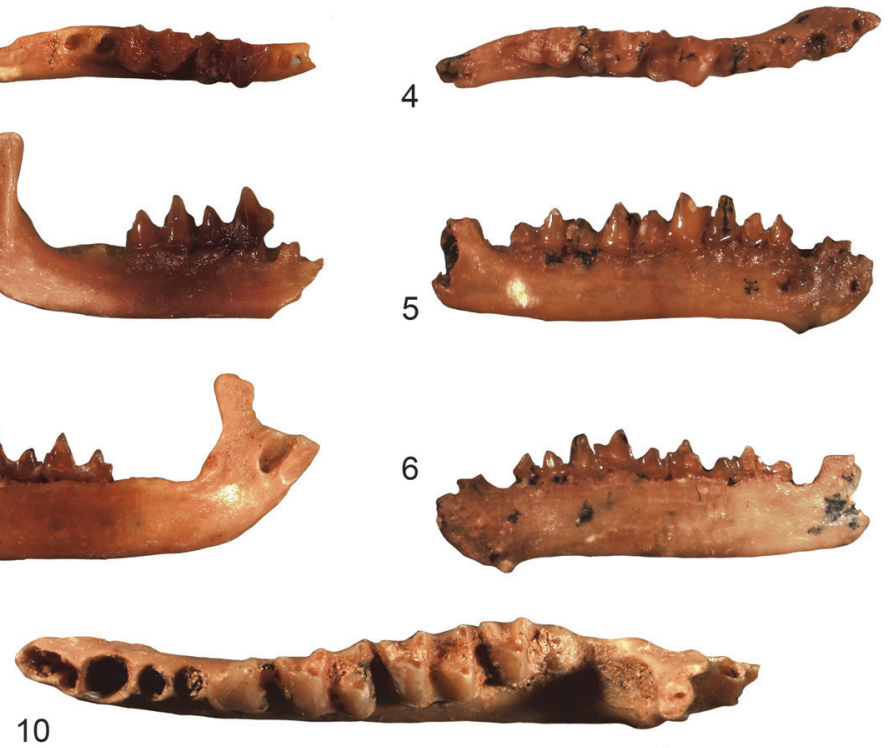

10

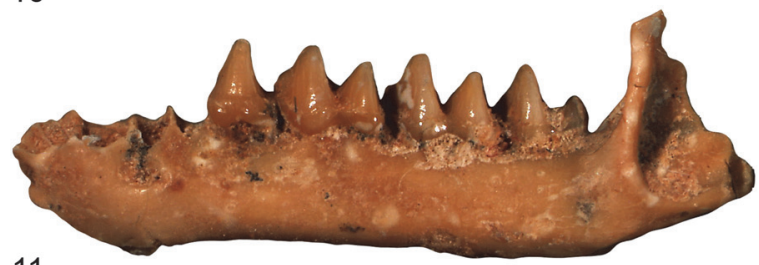

11

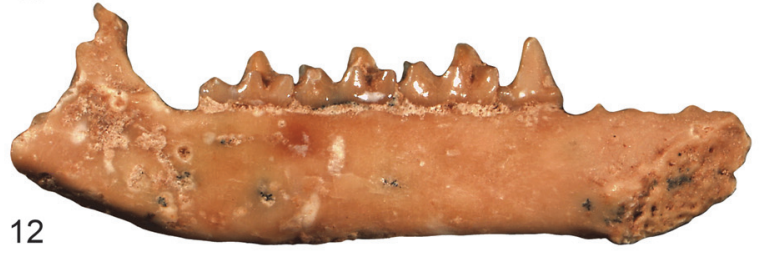

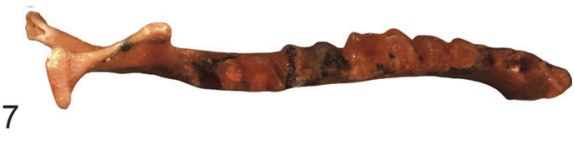

8

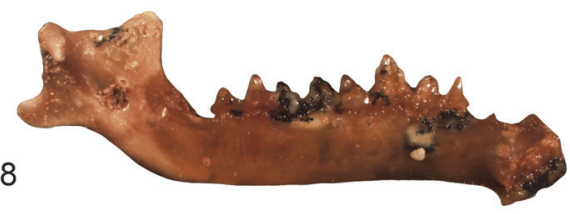

9

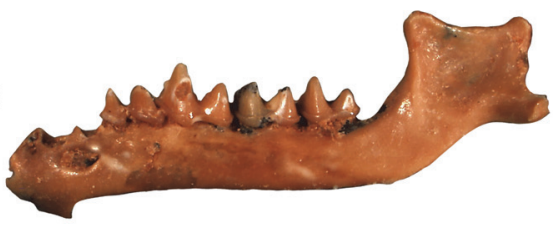

13

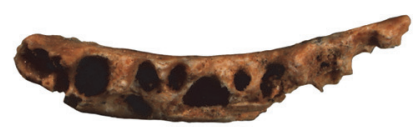

14

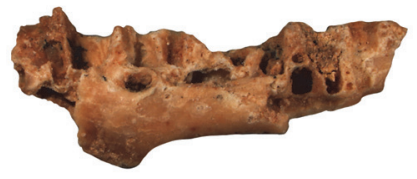

$1 \mathrm{~mm}$

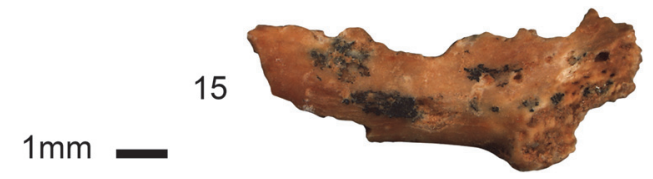

FIGURE 4. Remains of (4.1-9) Miniopterus cf. schreibersii (Kuhl, 1817), and (4.10-15) Myotis blythii (Tomes, 1857) from the Middle Pleistocene Qesem Cave: (4.1-3) TAU-QC/CHIR-04, right mandibular fragment, occlusal, buccal, lingual view; (4.4-6) TAU-QC/CHIR-07, left mandibular fragment, occlusal, buccal, lingual view; (4.7-9) TAU-QC/CHIR48, left mandibular fragment, occlusal, lingual, buccal view; (4.10-12) TAU-QC/CHIR-40, left mandibular fragment, occlusal, buccal, lingual view; (4.13-15) TAU-QC/CHIR-02, left mandibular fragment, occlusal, buccal, lingual view.

Africa (Miller-Butterworth et al., 2005). It would thus be quite important to establish a precise species identity of the fossil material under study. The respective information would address the liveliest topics of the historical biogeography of Levant i.e., the course of replacement of the Palaearctic and Ethiopian elements (M. schreibersii vs. M. pallidus) and the timing of particular events of that kind (Tchernov, 1992). Yet the task is beyond the scope of current possibilities.

Šrámek (2010), who analysed a large museum collection of Miniopterus from the Mediterranean region using both morphometric and genetic techniques, did not succeed in finding robust morphometrical differences discriminating M. schreibersii and M. pallidus except for some- what larger dimensions in the latter. It can thus be concluded that the majority of elements under study fall within the range of variation of extant $M$. schreibersii, but one specimen (TAU-QC/CHIR-7a) clearly exceeds it and corresponds well to the state in M. pallidus. Unfortunately, the Qesem sample is still too scarce to provide a robust proof of the simultaneous occurrence of both species or to allow any further conclusions. Both species (like all other species of the genus) are strict cave-dwellers, highly social, with large colonies in deep spacious chambers. In time of seasonal migrations they form small groups which may temporarily shelter even in small underground cavities or rock shelters. This could be the case of the remains appearing in Qesem Cave. 
Miniopterus as a typical cave-dweller appears regularly in the fossil record of karstic sites in Europe since the Miocene (MN6 M. fossilis Zapfe, 1950). It was reported from at least eight Pliocene and 18 Pleistocene sites, from Spain, France, Austria, Hungary, Czech Republic, Slovakia, Romania, and Bulgaria. A vast majority of the fossil material has been identified with extant type species of the genus, M. schreibersii (Kuhl, 1817). Two Pliocene forms were described: $M$. approximatus Woloszyn, 1987 (MN14 Podlesice, Poland), differing from schreibersii by an archaic arrangement of dentition (prolonged premolar row etc.), and $M$. horaceki Gunnell et al., 2011 (MN16 Ahl al Oughlam, Morocco), which is considerably larger.

Family VESPERTILIONIDAE Gray, 1821

Genus MYOTIS Kaup, 1829

Myotis blythii (Tomes, 1857)

Figure 4.10-15

Material. Two mandible fragments TAU-QC/CHIR02: (c-p4 md fragment without teeth of a juvenile individual), TAU-QC/CHIR-40: i-m3 (10.83, c-m3 (9.63, p4-m3 7.20, m1-m3 5.77, m1-m2 3.94, m2m3 3.83, p4-m1 3.40, c-p4 3.78, c-m1 5.75, symphysis $3.30 \times 1.12, \mathrm{mdH} 2.27, \mathrm{cL}(0.97), \mathrm{cW}(0.94)$, p2L (0.64), p3L (0.54), p4L 1.38, p4W 1.00, m1L 1.98, m1trL 1.03, m1trW 1.16, m1tIW 1.48, m2L 2.02, m2trL 1.05, m2trW 1.37, m2tIW 1.49, m3L 1.76, m3trL 0.88, m3trW 1.26, m3tIW 0.88.

Remarks. It is a large-sized form of the genus Myotis. The group is represented in the Western Palaearctic by a complex of sibling, partly hybridizing species (Berthier et al., 2006). In the Levant, the largest form of the group $M$. myotis macrocephalicus occurs in Lebanon together with distinctly smaller M. blythii oxygnathus-omari. The Qesem Cave fossils clearly fall in the variation range of the latter form to which they correspond also in all dental characters, including the premolar row which is relatively less compressed than in $M$. myotis. Worth mentioning is that one of the two specimens, the toothless fragment TAU-QC/CHIR-02, obviously belongs to a juvenile individual of an age close to weaning time. This might suggest the presence in the vicinity of a breeding colony roost, which for M. blythii in the Levant should be a large spacious cave.

Bate (1937) identified a large-sized form of Myotis in Tabun layer Ed (i.e., the layer synchronous to Qesem Cave) as Myotis baranensis Kormos based on a less reduced $\mathrm{m} 3$ and more pronounced hypoconulid on that tooth. Yet, these characters are not obvious in the type of $M$. baranensis (Villány 3, MN17) that is generally smaller $(\mathrm{c}-\mathrm{m} 3=8.99, \mathrm{c}-\mathrm{m} 1=5.26, \mathrm{~m} 1-\mathrm{m} 3=5.39$, $\mathrm{p} 4-\mathrm{m} 1=3.09-$ own measurements). The differences mentioned by Bate (1937) seem to fall in the range of variation of the extant $M$. blythii/oxygnathus complex.

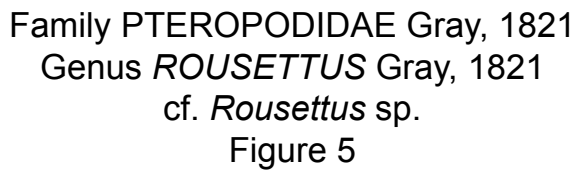

Material. TAU-QC/CHIR-51: left $\mathrm{C}$ fragment of a tooth tip without basal cingulum, $\mathrm{W}$ at the base 2.80, $\mathrm{H}$ (height of the crown without cingulum) 4.90, TAU-QC/CHIR-29: fragment of ?M1 (W 2.9). $\mathrm{MNI}=2$.

Remarks. The two tooth fragments are the most exciting items in the Qesem Cave bat collection. Their morphology excludes referral to any mammalian order but Chiroptera. In size they exceed all other bat remains from Qesem Cave.

The canine fragment is characterized by a broad medial ridge at its concave distal face, which is surrounded by distinct lateral grooves, and by a broad smooth convex mesial face. The molar fragment has a massive knob-like structure with a flat central basin surrounded by a slightly inflated palatal margin and relatively high blunt cusp at its buccal margin. Teeth of such characteristics occur in fruit bats, including the extant Levantine species Rousettus aegyptiacus Geoffroy, 1810, for which no fossil record older than Holocene was available until now.

However, both fragments from Qesem Cave differ in some respect from the extant $R$. aegyptiacus. First, they are larger. The canine fossil measures $2.8 \mathrm{~mm}(\mathrm{~W})$ and $4.9 \mathrm{~mm}(\mathrm{H})$, compared with the maximum values of $2.45 \mathrm{~mm}$ and $4.65 \mathrm{~mm}$ found in a large sample of an Egyptian population (the largest western Palaearctic form, $n=250$ ). The M1 width of the Qesem specimen is $2.9 \mathrm{~mm}$, in comparison to maximum values of $2.25 \mathrm{~mm}$ in the extant species. Moreover, the fossil canine fragment exhibits a more pronounced difference in enamel thickness between its mesial and distal faces than in the extant form. In extant $R$. aegyptiacus, despite certain variation, the M1 buccal cusp is situated rather at the mesial part of the tooth and tends to form a continuous ridge along the crown margin (Figure 6). Metrically, the fragments from Qesem might fall at lower variation limits of the central African fruit bat Eidolon helvum, but its differences in shape of the corresponding teeth are even more pronounced than the differences to the extant $R$. aegyptiacus. M1 of Eidolon is shorter and more robustly built, and the canine is less curved, 


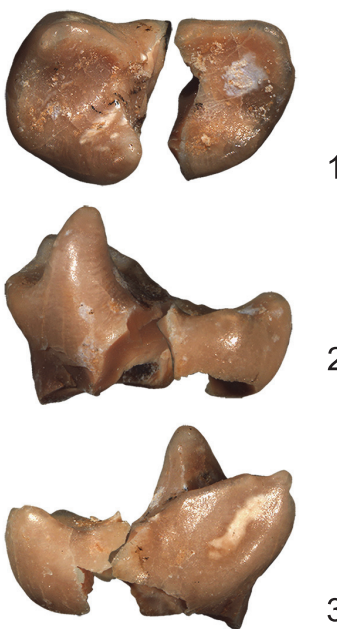

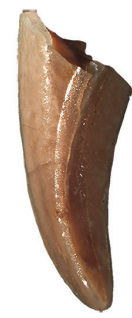

4

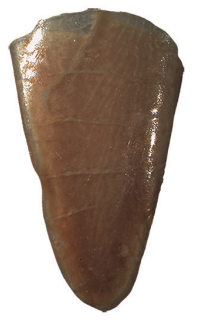

5

$1 \mathrm{~mm}$

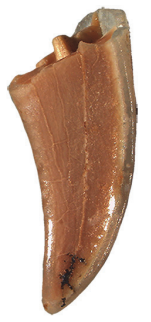

6

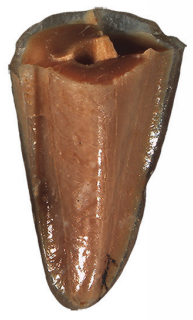

7

FIGURE 5. Remains of cf. Rousettus sp. from the Middle Pleistocene Qesem Cave: (5.1-3) TAU-QC/CHIR-26: right ?M1 fragment, occlusal, buccal, lingual view; (5.4-7) TAU-QC/CHIR-51: left C fragment, buccal, mesial, palatal, distal view.

more rounded on section and its medial ridge is much less distinct than in Rousettus (Figure 6). The same holds also for other fruit bats (such as Epomophorus spp., common in sub-Saharan Africa) which are, moreover, distinctly smaller.

The difference between the fossil fruit bat remains from Qesem Cave and the extant Rousettus aegyptiacus obviously exceeds a level of intraspecific variation. The morphological similarities, however, support referral to the same genus.

\section{DISCUSSION}

\section{Species Composition and Palaeoenvironmental Context}

The vast majority of the bat fossil record comes from palaeokarst deposits. This is also the case in the Levant. However, only about half of the bat species are true cave-dwellers, and only some of them are strictly confined to cave roosts. Among the Near Eastern bats these are Rhinolophidae, Hipposideridae, Miniopteridae and some species of the genus Myotis ( $M$. capaccinii, M. emarginatus, M. blythii, M. myotis). Naturally, these taxa predominate in the fossil record.

The five microchiropteran species identified at Qesem Cave (Rhinolophus ferrumequinum, $R$. euryale, R. mehelyi, Miniopterus cf. schreibersii, Myotis blythii) are in full accordance with this consideration. Their habitat requirements also support quite well the preliminary reconstructions of the palaeoenvironmental context of the site at the time of deposition based on the hitherto recorded microvertebrate assemblage (Maul et al., 2011) - a variegated mosaic of open and woodland habitats, corresponding to contemporary conditions of the thermomediterranean vegetation zone of the southern Levant (in the sense of Blondel et al., 2010). All bat taxa recorded at Qesem Cave belong to the most typical cave-dwelling species characterizing bat communities of just that zone. This is true also for fruit bats of the genus Rousettus. Except for cf. Rousettus, all bats from Qesem belong to clades disposed to respond to seasonal or temporal temperature fluctuation characterizing the contemporary thermomediterranean zones with a prolonged torpidity or hibernation.

Rousettus aegyptiacus, which also belongs to the extant bat fauna of Israel, was abundant since the Neolithic period, possibly due to the anthropogenic spread of fruit trees such as Ficus sycamora (Tchernov, 1984). The fruit bat from the Middle Pleistocene of Qesem Cave ( $\mathrm{MNI}=1)$ tentatively referred to this genus might then represent the first real fossil record of Rousettus.

\section{Palaeobiogeography}

Although the fossil record of bats is still very scarce in the Near East the current data suggest several important palaeobiogeographic conclusions. Some of them are supported also by the bat record from Qesem Cave, despite its fragmentarity and low abundance. Nevertheless, a few comments can be made. First is the conspicuous correspondence in species composition to other Middle and Late Pleistocene fossil sites from the region. The same species are presently the most typical elements of the cave-dwelling bat assemblages of 

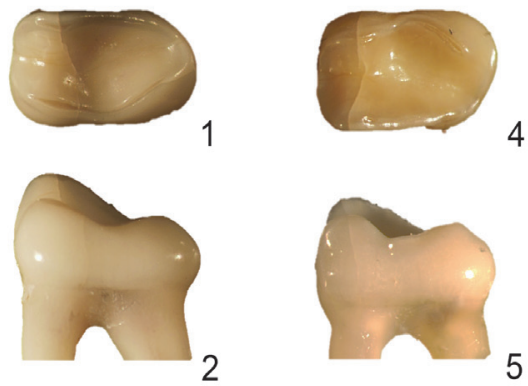

4
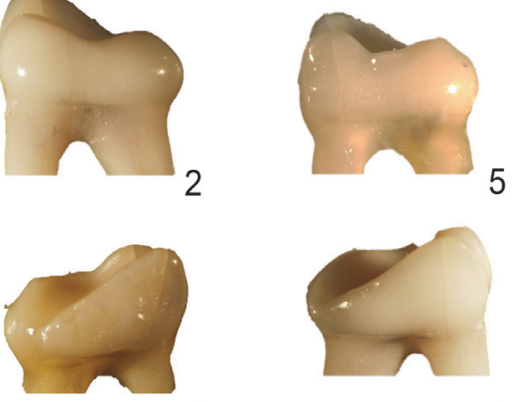

3
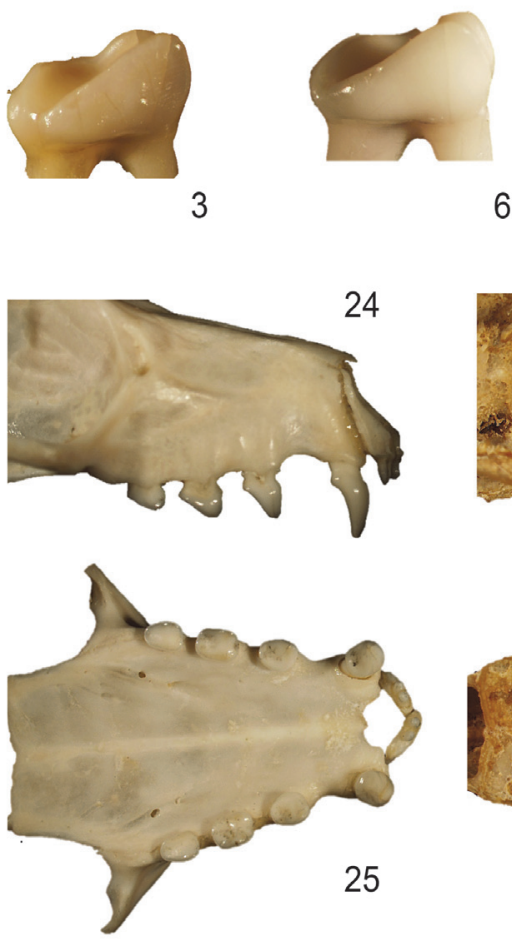

$10 \mathrm{~mm}(24-27)$

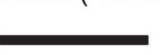

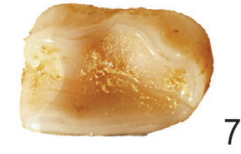

$1 \mathrm{~mm}$
6

6
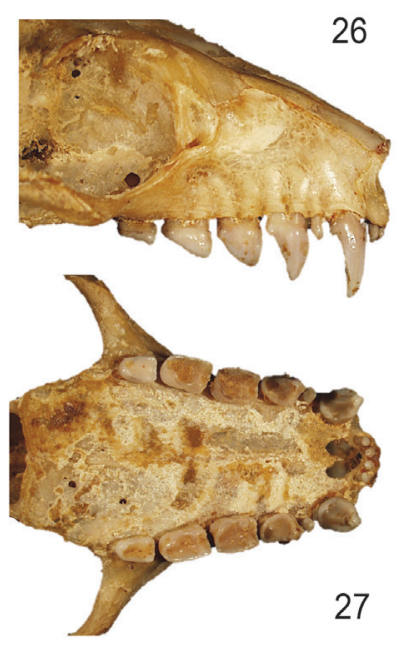
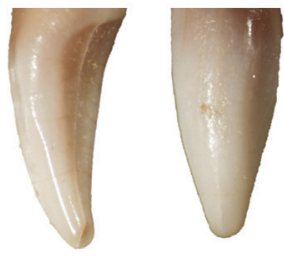

8

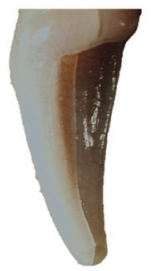

9

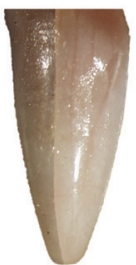

12

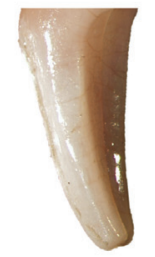

16

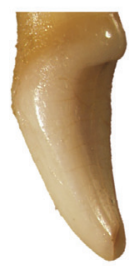

20
13

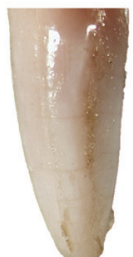

17

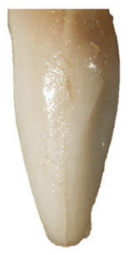

21

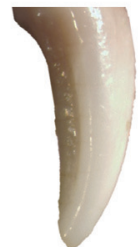

10

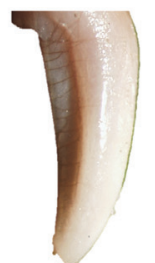

14

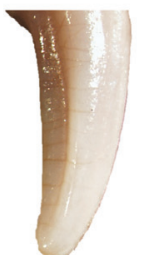

18

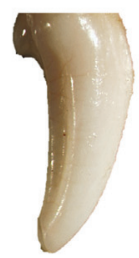

22

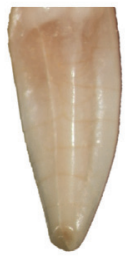

11

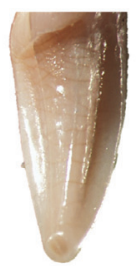

15

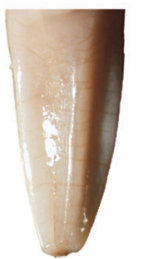

19

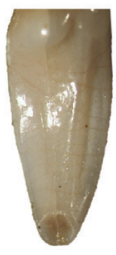

23

FIGURE 6. Extant Rousettus aegyptiacus (Qualamun, Dakhla, Egypt, Coll. Univ. Praha): (6.1 -7) M1 and (6.8-23) C. The views correspond to those of the fossil specimens figured in Figure 5. Upper dentitions of extant (6.24-25) EidoIon helvum (Malawi, Coll. Univ. Ceske Budejovice) and (6.26-27) Rousettus aegyptiacus (Rash130, Dakhla, Egypt, Coll. Univ. Praha), lateral and palatal views.

the East Mediterranean. The repeating pattern in all sites suggests remarkable stability of the fauna and unexpectedly little variation in community composition. Yet, at the same time the above mentioned phenotypic differences of some Levant fossil forms (e.g., for Rhinolophus ferrumequinum) indicates that the common faunal structure is combined here with stable local particularities. Therefore unique faunal phenomena can be expected.

First of all, it concerns the likely occurrence of a fruit bat in the Qesem fauna. The extant population of Rousettus aegyptiacus inhabiting the Eastern Mediterranean and Near East regions presents the only offshoot of the family Pteropodidae beyond the limits of the tropics. Until now, no fossil record was available except for those of the Neolithic and post-Neolithic in Sefunim cave (Tchernov, 1984). There are several Miocene records in the Mediterranean region obviously representing Rousettus (at least four sites in southern France - Sigé and Aguilar, 1987). Although the current distribution range of the species in the region was considerably influenced by anthropogenic factors (Benda et al., 2010), and although genetic data suggest a recent star-like radiation (Hulva et al., 2012), there are more reasons to believe that the genus appeared in the region much earlier (Benda et al., 2007). The Qesem record seems to support such a possibility.

Another intriguing curiosity in the fossil bat fauna of Israel concerns Megaderma, now a strictly 
tropical genus, with Pakistan and SE Afghanistan (Corbet and Hill, 1992) being its closest approach to Levant. Our re-examination of the type material of Megaderma watwat from Tabun layer $\mathrm{F}$ confirmed the reliability of Bate's (1937) description, including all its curious specificities. In comparison to other megadermatids, it is of extremely large size (larger than all extant species except for the Australian Macroderma gigas), and it exhibits a clear shortening of the premolar row, which indicates a more pronounced emphasis on large-sized prey. The genus Megaderma was widely distributed in Europe until the early Pliocene, with a last appearance during MN15 at Osztramos 10 (Topál, 1974) and Sète (Sigé, 1974). Its retreat from Europe was obviously driven by a more pronounced seasonality accompanying climatic changes of the Late Cenozoic, which the representatives of bat clades incapable of hibernation (like Megaderma) could not survive (Horáček et al., 2000). The Pleistocene record of Megaderma watwat suggests that in the Levant, the critical stress of the Late Cenozoic climatic development was much less pronounced, at least until the early Middle Pleistocene and that in this region, independently of the other clades of the genus, a remarkable phenotypic rearrangement evolved. In short, the Levant could obviously act as a refugium of West Palaearctic Neogene biota until the early Middle Pleistocene and, per analogiam it can be expected also for other taxa of similar range histories such as hipposiderids, emballonurids, and rhinopomatids. Yet, the fossil record of these groups from the Levant is still missing.

In these regards, the assumed first Pleistocene record of Rousettus sp., reported in this paper, is of particular importance. Correspondingly to Megaderma, it suggests for the Rousette fruit bat (a) a presence of a relict population in Levant accompanied by (b) phenotypic rearrangements including increased body size. Then, the specificities of the extant Levant population of Rousettus aegyptiacus, i.e., a larger body size and higher genetic diversity compared to neighbouring populations (cf. Benda et al., 2012; Hulva et al., 2012), could be tentatively explained by assimilation of the local relict form into the Holocene expansion of Rousettus aegyptiacus promoted by anthropogenic spread of its food resources (Phoenix dactylifera, Ficus spp., Ceratonia siliqua, Morus nigra a.o.).

The particularity of the Levant fauna is corroborated also by other small mammal taxa. Similar, unresolved question concerns taxonomic identification of a large-sized 'Crocidura' appearing in several fossil assemblages in the Levant, including Qesem Cave (Maul et al., 2011), with Suncus murinus. This species is naturally distributed today in southern and SE-Asia (with western marginal records in Afghanistan and Pakistan - cf. Corbet and Hill, 1992), and extant occurrences in the Near and Middle East (Iran, Yemen, Egypt) are believed to originate from recent introductions into the region. Tchernov (1992), however, also identified the species in the Mousterian site Qafzeh in the Lower Galilee and suggested the possibility that Suncus murinus represents a palaeochoric element in the Levant, though it does not appear there at present (Mendelssohn and Yom-Tov, 1999).

It should be stressed that the Qesem assemblages of small ground mammals are almost exclusively composed of Western Palaearctic elements (perhaps except for Gerbillus and Meriones), whereas none of the numerous Ethiopian and eremial (xeric) elements, which comprise nearly half of the species pool of the contemporary Levantine fauna, is a significant component of the fossil record during the Middle and Late Pleistocene. Despite the fact that the fossil record of bats from that region is still too scarce for any definite conclusions, its structure suggests exactly the same. All the elements appearing in the fossil record (including those appearing in the Qesem assemblages) are elements of the Palaearctic clades. Their sister taxa characterizing Ethiopian influences (Rhinolophus clivosus, R. blasii, Miniopterus pallidus) are missing, notwithstanding the fact that other Ethiopian elements form a considerable part of the extant Levantine fauna (Taphozous, Rhinopoma, Otonycteris, Nycteris etc.). Megaderma and Rousettus (if the respective fossils belong indeed to the genus), the current ranges of which are centered beyond the limits of the Palaearctic region seemingly contradict the above conclusion, call for a special comment. Both these clades were present in Miocene faunas of the Mediterranean region (for Rousettus cf. Aguilar et al., 1986; Sigé and Aguilar, 1987; Sigé et al., 1997), and it cannot be excluded that the relict populations of these clades survived in the Levant region until Pleistocene or even (as presumed for Rousettus) Holocene age, and both these taxa could be considered as the palaeochoric elements of the Palaearctic.

Together with the aforementioned implications, all this suggests considerable stability of the chorologic setting of the Levantine biota during the Middle and Late Pleistocene and their obvious relation to the West Palaearctic-Mediterranean chorologic unit, for which the Levant supposedly 
has always provided one of the most important refugia.

\section{Taphonomy}

Abundant fossil assemblages of bat remains typically represent thanatocoenoses in context of roosts of bat colonies. As the roost preferences of individual bat species often differ quite considerably, the species composition of such assemblages provides quite reliable information on microclimate and the contextual characteristics of the site in the time of deposition. However, bats might also be preyed upon by owls and other raptors in flight and in their roosts. In particular areas and under particular ecological conditions, in owl pellets of the opportunistic hunting owls (Tyto alba, Strix aluco) bat remains are not too rare (e.g., Steiner, 1961; Schmidt and Topál, 1971; Krzanowski, 1973; Vargas et al., 2002; Sommer et al., 2009).

At Qesem, bat remains do not occur in large numbers. Instead, they comprise a rather low percentage of the microvertebrate finds - out of more than 15,000 remains of microvertebrates identified to the family, genus, or species level only some 53 skeletal and dental elements $(<0.3 \%)$ belong to bats. In most instances these are fragments of mandibles and small fragments of long bones. Isolated teeth (except for the largest - upper canine of Rhinolophus ferrumequinum) are absent despite the fact that soricid molars of similar size have been recorded. This might be due to the greater number of shrew remains (already the preserved mandibles and maxillae are $>100$ ) in the fossil material.

At Qesem Cave the majority of microvertebrate remains are concentrated in two areas: Squares H/16-17 and L-M-N/13-15. Moreover, in these squares these remains are restricted to specific stratigraphic horizons. All other squares yielded none or only very few such finds (Figure 2). All bat remains exclusively originate from these two areas. Rhinolophus ferrumequinum, $R$. mehelyi, $R$. euryale, and Miniopterus cf. schreibersii occur in both microvertebrate rich areas, whereas Myotis blythii is recorded only in Squares M-N/13-14. Both fragments referred to Rousettus originate from one square $H / 16$. However, the molar fragment occurred at the elevation $645-650$ whereas the canine was found at the elevation $680-685$. It is too speculative to conclude whether or not they belong to one individual.

The scarce amount of recorded elements and the disproportionate representation of particular skeletal elements indicate an accumulation in owl pellets (e.g., Maul et al., 2011; Smith et al., 2013) rather than a direct deposition in a roost, where more complete skeletal material should be expected. In other words most of the bat remains seem to belong to a taphocoenosis rather than to a thanatocoenosis. Even Rousettus might be prey of Tyto alba; this is known at least for R. madagascariensis, which is slightly smaller than $R$. aegyptiacus (Goodman and Griffiths, 2006). In our own sample of Tyto alba pellets from the E Mediterranean (20 sites, MNI >9,500) Rousettus aegyptiacus appeared in two localities (S Turkey, Lebanon) with a percentage of about $0.01 \%$ (Šindelář, 2012).

Except for one mandible fragment of $M$. blythii (TAU-QC/CHIR-02), all the remains belong to adult individuals. Yet the immature individual of $M$. blythii at an age just about weaning in Squares M-N/14 could indicate presence of a breeding colony either in the site or in close vicinity.

Summarizing, we suggest that the bat remains, on account of their scarcity, do not indicate presence of larger assemblages inside the cave. However, it cannot be definitely excluded that the cave was temporarily used by smaller colonies or solitary individuals. All other microvertebrate remains originate with high probability from pellets concentrated in two places, thought to be located underneath the owl roosts (Smith et al., 2013).

\section{CONCLUSION}

Although only scarce bat specimens were found among copious remains of small vertebrates in Qesem Cave, their evaluation provides valuable information concerning two major issues.

1. It supplements existing data on the palaeoecological and palaeobiogeographical setting of the fauna. (i) The bat remains are little differentiated taxonomically or morphometrically from extant local forms, which suggests remarkable stability of the faunal structure of the region. (ii) They indicate diversified habitats at the time of deposition, corresponding to present-day conditions of the thermomediterranean zone. (iii) Rather than signs of active visits of bats in the cave we consider the accumulation of the remains as owl prey (cf. Smith et al., 2013). (iv) In agreement with the signal from other small vertebrates (cf. Maul et al., 2011) the Qesem Cave bat fauna is dominated by elements of the extant Western Palaearctic faunal unit. The afro-eremial elements, now common in the southern Levant, 
including Israel, were absent in the Middle Pleistocene sites.

2. The record of Rousettus is of particular significance. Rousettus, now known from Qesem, like Megaderma (known from somewhat older deposits of Tabun F), is a clade whose current range is centered beyond the limits of the Palaearctic region. The fossil record suggests that relict populations of these clades survived in the Levant region until Pleistocene or even (as presumed for Rousettus) Holocene time and that Rousettus could be a palaeochoric element of the Palaearctic fauna. Taking into account the absence of Afro-eremial elements at Qesem Cave and other Pleistocene sites as late as the Mousterian, all this suggests considerable stability of the chorologic setting of the Levantine biota during the Middle and Late Pleistocene and their obvious relation to the West Palaearctic-Mediterranean chorologic unit, for which it supposedly has always provided one of the most important refugia.

\section{ACKNOWLEDGEMENTS}

We thank several organisations that financially supported the excavation at Qesem Cave: the Israel Science Foundation, the Leakey Foundation, the Wenner Gren Foundation, the CARE Archaeological Foundation, the Dan David Foundation and the Fritz Thyssen Foundation. We thank Karin Drechsel (Erftstadt/Germany) for the graphics. R. Rabinovitch (Hebrew University Jerusalem/ Israel) kindly enabled to study the material of fossil bats deposited in the Hebrew University Jerusalem and provided valuable discussions. Grants IAA601110905 and GACR206/09/0888 provided financial support to I. Horáček. We are grateful to the anonymous reviewers who provided valuable comments.

\section{REFERENCES}

Aguilar, J.-P., Calvet, M., Crochet, J.-Y., Legendre, S., Michaux, J., and Sigé, B. 1986. Première occurrence d'un mégachiroptère ptéropodidé dans le Miocène moyen d'Europe (gisement de Lo Fournas-II, Pyrénées-Orientales, France). Paleovertebrata, 16:173-184.

Agustí, J., Santos Cubedo, A., Furió Bruno, M., de Marfà Taillefer, R.J., Blain, H.A., Oms Llobet, O., and Sevilla García, P. 2011. The late Neogene-early Quaternary small vertebrate succession from the Almenara-Casablanca karst complex (Castellón, Eastern Spain): Chronologic and paleoclimatic context. Quaternary international, 243 183-191.
Allen, H.D. 2009. Vegetation and ecosystem dynamics, p. 203-227. In Woodward, J.C. (ed.), The Physical Geography of the Medierranean. Oxford University Press, Oxford.

Andersen, K., Matschie, G. 1904. Uebersicht einiger geographischen Formen der Untergattung Euryalus. Sitzungsberichte Gesellschaft naturforschenden Freunde Berlin 1904: 71-83.

Aulagnier, S., Haffner, P., Mitchelll-Jones, A., Motou, F., and Zima, J. 2009. Mammals of Europe, North Africa and the Middle East. A\&C Black Publishers, London.

Barkai, R. and Gopher, A. 2011. Innovative human behavior between Acheulian and Mousterian: A view from Qesem Cave, Israel. In Le Tensorer, J.-M., Jagher, R., and Otte, M. (eds.), The Lower and Middle Palaeolithic in the Middle East and Neighbouring Regions. Etudes et Recherches Archéologiques de L'Université de Liège (ERAUL). Université de Liege, Liege.

Barkai, R., Gopher, A., and Shimelmitz, R. 2005. Middle Pleistocene Blade Production in the Levant: An Amudian Assemblage from Qesem Cave, Israel. Eurasian Prehistory, 3:39-74.

Barkai, R., Gopher, A., Lauritzen, S.E., and Frumkin, A. 2003. Uranium series dates from Qesem Cave, Israel, and the end of the Lower Palaeolithic. Nature, 423:977-979.

Barkai, R., Lemorini, C., Shimelmitz, R., Lev, Z., Stiner, M.C., and Gopher, A. 2009. A blade for all seasons? Making and using Amudian blades at Qesem Cave, Israel. Human Evolution, 24:57-75.

Bate, D.M.A. 1937. Part II. Palaeontology: The Fossil Fauna of the Wady El-Mughara Caves., p. 136-233. In Garrod, D.A.E. and Bate, D.M.A. (eds.), The Stone Age of Mount Carmel. Excavations at the Wady ElMughara. Volume I. Clarendon Press, Oxford.

Ben-Dor, M., Gopher, A., Hershkovitz, I., and Barkai, R. 2011. Man the Fat Hunter: The Demise of Homo erectus and the Emergence of a New Hominin Lineage in the Middle Pleistocene (ca. 400 kyr) Levant. PLOS ONE, 6:e28689.

Benda, P., Vallo, P., Hulva, P., and Horáček, I. 2012. The Egyptian fruit bat Rousettus aegyptiacus (Chiroptera: Pteropodidae) in the Palaearctic: Geographic variation and taxonomic status. Biologia 67:1230-1244.

Benda, P., Hanák, V., Horáček, I., Hulva, P., Lučan, R.K., and Ruedi, M. 2007. Bats (Mammalia: Chiroptera) of the Eastern Mediterranean. Part 5. Bat fauna of Cyprus: review of records with confirmation of six species new for the island and description of a new subspecies. Acta Societatis Zoologicae Bohemicae, 71:71-130.

Benda, P., Andreas, M., Kock, D., Lučan, R.K., Munclinger, P., Nová, P., Obuch, J., Ochman, K., Reiter, A., Uhrin, M., and Weinfurtová, D. 2006. Bats (Mammalia: Chiroptera) of the Eastern Mediterranean. Part 4. Bat fauna of Syria: distribution, systematics, ecology. Acta Societatis Zoologicae Bohemicae, 70:1329. 
Benda, P., Lucan, R.K., Obuch, J., Reiter, A., Andreas, M., Backor, P., Bohnenstengel, T., Eid, E., Ševcik, M., Vallo, P., and Amr, Z.S. 2010. Bats (Mammalia: Chiroptera) of the Eastern Mediterranean and Middle East. Part 8. Bats of Jordan: fauna, ecology, echolocation, ectoparasites. Acta Societatis Zoologicae Bohemicae, 74:185-353

Berthier, P., Excoffier, L., and Ruedi, M. 2006. Recurrent replacement of mtDNA and cryptic hybridization between two sibling bat species Myotis myotis and Myotis blythii. Proceedings of the Royal Society (B), 273:3101-3109.

Bilgin, R. 2011. Back to the Suture: The Distribution of Intraspecific Genetic Diversity in and Around Anatolia. International Journal of Molecular Science, 12:4080-4103.

Bilgin, R., Karataş, A., Çoraman, E., Pandurski, I., Papadatou, E., and Morales, J.C. 2006. Molecular taxonomy and phylogeography of Miniopterus schreibersii (Kuhl, 1817) (Chiroptera: Vespertilionidae), in the Eurasian transition. Biological Journal of the Linnean Society, 87:577-582.

Blasius, J.H. 1853. Beschreibung zweier neuer deutscher Fledermausarten. Archiv für Naturgeschichte, 19:35-57.

Blondel, J. 2009. The Nature and Origin of the Vertebrate fauna, p. 139-163. In Woodward, J.C. (ed.), The Physical Geography of the Medierranean. Oxford University Press, Oxford.

Blondel, J. and Aronson, J. 1999. Biology and Wildlife of the Mediterranean Region. Oxford University Press, Oxford.

Blondel, J., Aronson, J., Bodiou, J.-Y., and Boeuf, G. 2010. The Mediterranean Region. Biological Diversity in Space and Time. Second Edition. Oxford University Press, Oxford.

Blumenbach, J.F. 1779. Handbuch der Naturgeschichte. J.C. Dieterich, Göttingen.

Bonaparte, C.L.J.L. 1837. Synopsis vertebratorum systematis. Nuovi Annali delle Scienze Naturali, 1:105133.

Boutié, P. 1979. Les Gisements moustériens de Palestine. Paléorient, 5:17-65.

Corbet, G.B. and Hill, J.E. 1992. The Mammals of the Indomalayan Region: A Systematic Review. Oxford University Press, Oxford.

De Paz, O. 1995. Geographic variation of the greater horseshoe bat (Rhinolophus ferrumequinum) in the west-half of the Palaearctic Region. Myotis, 3233:33-34.

Dobson, G.E. 1875. Conspectur or the Suborders, Families, and Genera of Chiroptera arranged according to their Natural Affinities. The Annals and Magazine of Natural History, fourth series, 16:345-357.

Dov Por, F. and Dimentman, C. 2006. Mare Nostrum. Neogene and antropic natural history of the Mediterranean basin, with emphasis on the Levant. Pensoft, Sofia, Moscow.
Flanders, J., Jones, G., Benda, P., Dietz, C., Zhang, S., Li, G., Sharifi, M., and Rossiter, S.J. 2009. Phylogeography of the greater horseshoe bat, Rhinolophus ferrumequinum: contrasting results from mitochondrial and microsatellite data. Molecular Ecology, 18:306-318.

Frumkin, A., Bar-Yosef, O., and Schwarcz, H.-P. 2011. Possible paleohydrologic and paleoclimatic effects on hominin migration and occupation of the Levantine Middle Paleolithic. Journal of Human Evolution 60:437-451.

Frumkin, A., Karkanas, P., Bar-Matthews, M., Barkai, R., Gopher, A., Shahack-Gross, R., and Vaks, A. 2009. Gravitational deformations and fillings of aging caves: The example of Qesem karst system, Israel. Geomorphology, 106:154-164.

Furman, A., Çoraman, E., Bilgin, R., and Karataş, A. 2009. Molecular ecology and phylogeography of the bent-wing bat complex (Miniopterus schreibersii) (Chiroptera: Vespertilionidae) in Asia Minor and adjacent regions. Zoologica Scripta, 38:129-141.

Gaisler, J. 2001. Rhinolophus mehelyi Matschie, 1901 Mehely-Hufeisennase, p. 91-104. In Niethammer, J. and Krapp, F. (eds.), Handbuch der Säugetiere Europas. Band 4: Fledertiere. Teil I: Chiroptera I. AULAVerlag, Wiesbaden.

Geoffroy-Saint-Hilaire, E. 1810. Description des rousettus et des céphalotes, deux noveaux genres de la famille des chauve-souris. Annales du Muséum d'Histoire Naturelles, 15:86-108.

Goldberg, P., Horowitz, A., Farrand, W.R., Jelinek, A.J., and Haas, G. 1973. New excavations at the Tabun cave, Mount Carmel, Israel, 1967-1972: A preliminary report. Paléorient, 1:151-183.

Goodman, S.M. and Griffiths, O. 2006. A case of exceptionally high predation levels of Rousettus madagascariensis by Tyto alba (Aves: Tytonidae) in western Madagascar. Acta Chiropterologica, 8:553-556.

Gopher, A., Ayalon, A., Bar-Matthews, M., Barkai, R., Frumkin, A., Karkanas, P., and Shahack-Gross, R. 2010. The chronology of the Late Lower Paleolithic in the Levant: $U$ series dates of speleothems from Middle Pleistocene Qesem cave, Israel. Quaternary Geochronology, 5:644-656.

Gopher, A., Barkai, R., Shimelmitz, R., Khalaly, M., Lemorini, C., Hershkovitz, I., and Stiner, M.C. 2005. Qesem Cave: An Amudian Site in Central Israel. Journal of the Israel Prehistoric Society 35:69-92.

Gray, J.E. 1821. On the natural arrangement of vertebrose animals. London Medical Repository, 15:296310.

Gray, J.E. 1825. Outline of an attempt at the disposition of the Mammalia into tribes and families with a list of the genera apparently appertaining to each tribe. Annals of Philosophy, n.s., ser. 2, 10:337-344.

Gunnell, G.F., Eiting, T.P., and Geraads, D. 2011. New late Pliocene bats (Chiroptera) from Ahl al Oughlam, Morocco. Neues Jahrbuch für Geologie und Paläontologie, Abhandlungen, 260:55-71. 
Haas, G. 1951. II. Remarques sur la microfaune de mammifères de la Grotte d'Oum-Qatafa, p. 218-233. In Neuville, R. (ed.), Le Paléolithique et le Mésolithique du désert de Judée. Masson et Cie Editeurs, Paris.

Haas, G. 1966. On the Vertebrate Fauna of the Lower Pleistocene Site 'Ubeidiya. The Israel Academy of Sciences and Humanities, Jerusalem.

Haas, G. 1967. Bemerkungen ueber die Fauna der Geula-Hoehle, Carmel. Quaternaria, 9:97-104.

Heller, F. 1936. Eine oberpliocäne Wirbeltierfauna aus Rheinhessen. Neues Jahrbuch für Mineralogie, Geologie und Paläontologie, Abteilung B, Beilagen-Band, 76:99-160+Taf. VII-XI.

Hershkovitz, I., Smith, P., Sarig, R., Quam, R., Rodríguez, L., García, R., Arsuaga, J.L., Barkai, R., and Gopher, A. 2011. Middle Pleistocene Dental Remains From Qesem Cave (Israel). American Journal of Physical Anthropology, 144:575-592.

Horáček, I., Hanák, V., and Gaisler, J. 2000. Bats of the Palaearctic region: A taxonomic and biogeographic review, p. 11-157. In Woloszyn, W. (ed.), Proceedings of the VIIIth EBRS, Kraków.

Hulva, P., Fornůsková, A., Chudárková, A., Evin, A., Allegrini, B., Benda, P., and Bryja, J. 2010. Mechanisms of radiation in a bat group from the genus Pipistrellus inferred by phylogeography, demography and population genetics. Molecular Ecology, 19:5417-5431.

Hulva, P., Horáček, I., Strelkov, P.P., and Benda, P. 2004. Molecular architecture of Pipistrellus pipistrellus/ Pipistrellus pygmaeus complex (Chiroptera: Vespertilionidae): further cryptic species and Mediterranean origin of divergence. Molecular Phylogenetics and Evolution, 32:1023-1035.

Hulva, P., Marešová, T., Dundarova, H., Bilgin, R., Benda, P., Bartonička, T., and Horáček, I. 2012. Environmental margin and island evolution in Middle Eastern populations of the Egyptian fruit bat. Molecular Ecology, 21:6104-6116.

Ibanez, C., García-Mudarra, J.L., Ruedi, M., Stadelmann, B., and Juste, J. 2006. The Iberian contribution to cryptic diversity in European bats. Acta Chiropterologica, 8:277-297.

Jánossy, D. 1996. Lower Pleistocene vertebrate faunas from the localities 16 an 17 of Beremend (Southern Hungary). Fragmenta Mineralogica et Palaeontologica, 18:91-102.

Juste, J., Ibanez, C., Munoz, J., Trujillo, D., Benda, P., Karatas, A., and Ruedi, M. 2004. Mitochondrial phylogeography of the long-eared bats (Plecotus) in the Mediterranean and Atlantic Islands. Molecular Phylogenetics and Evolution, 31:1114-1126.

Kaup, J.J. 1829. Skizzirte Entwickelungs-Geschichte und Natürliches System der Europäischen Thierwelt. Leske, Darmstadt.

Kryštufek, B. 1993. Geographic variation in the Greater horseshoe bat Rhinolophus ferrumequinum in southeastern Europe. Acta Theriologica, 38:67-79.
Krzanowski, A. 1973. Numerical Comparison of Vespertilionidae and Rhinolophidae (Chiroptera: Mammalia) in the Owl Pellets. Acta zoologica cracoviensia, 18:133-140.

Kuhl, H. 1817. Die deutschen Fledermäuse, Hanau.

Lacépède, B.G.d. 1799. Mémoire sur une nouvelle table méthodique des animaux à mamelles. Mémoires de I'Institut National des Sciences et des Arts. Sciences Mathématiques et Physiques 3:469-502.

Lemorini, C., Stiner, M.C., Gopher, A., Shimelmitz, R., and Barkai, R. 2006. Use-wear analysis of Amudian laminar assemblage from the Acheuleo-Yabrudian of Qesem Cave. Journal of Archaeological Science, 33:921-934.

Matschie, G.F.P. 1901. Über rumänische Säugethiere. Sitzungsberichte der Gesellschaft naturforschender Freunde zu Berlin:220-238.

Maul, L.C., Smith, K.T., Barkai, R., Barash, A., Karkanas, P., Shahack-Gross, R., and Gopher, A. 2011. Microfaunal remains at Middle Pleistocene Qesem Cave, Israel: Preliminary results on small vertebrates, environment and biostratigraphy. Journal of Human EvoIution, 60:464-480.

Médail, F. and Diadema, K. 2009. Glacial refugia influence plant diversity pattern in the Mediterranean. Journal of Biogeography, 36:1333-1345.

Mein, P. 1965. Chiroptera (Miocene) de Lissieu (Rhone). Compter Rendus du 89eme Congres national des Societes savantes, Section Sciences:237-253.

Mein, P. and Tupinier, Y. 1977. Formule dentaire et position systématique du Minioptère (Mammalia, Chiroptera). Mammalia 41:207-211.

Mendelssohn, H. and Yom-Tov, Y. 1999. Fauna Palaestina. Mammalia of Israel. The Israel Academy of Sciences and Humanities, Jerusalem.

Mercier, N., Valladas, H., Falguères, C., Shao, Q., Gopher, A., Barkai, R., Bahain, J.-J., Vialettes, L., Joron, J.-L., and Reyss, J.-L. 2013. New datings of Amudian layers at Qesem Cave (Israel): results of TL applied to burnt flints and ESR/U-series to teeth. Journal of Archaeological Science, 40:3011-3020.

Miller-Butterworth, C.M., Eick, G., Jacobs, D.S., Schoeman, M.C., and Harley, E.H. 2005. Genetic and phenotypic differences between South African longfingered bats, with a global miniopterine phylogeny. Journal of Mammalogy, 86:1121-1135.

Popov, V.V. 2004. Pliocene small mammals (Mammalia, Lipotyphla, Chiroptera, Lagomorpha, Rodentia) from Muselievo (North Bulgaria). Geodiversitas, 26:403491.

Popov, V.V. and Ivanova, T. 2002. Comparative craniometrical analysis and distributional patterns of medium-sized horseshoe bats (Chiroptera, Rhinolophidae) in Bulgaria. Folia Zoologica, 51:187-200.

Quézel, P. 1985. Definition of the Mediterranean region and the origin of its flora, p. 9-24. In Gomez-Campo, C. (ed.), Plant conservation in the Mediterranean area. Geobotany 7. W. Junk, Dordrecht. 
Salicini, I., Ibanez, C., and Juste, J. 2012. Deep differentiation between and within Mediterranean glacial refugia in a flying mammals, the Myotis nattereri bat complex. Journal of Biogeography, 40:1182-1193.

Sapper, N. 1997. Hufeisennasen (Rhinolophiden - Chiroptera, Mammalia) im pleistozänen Höhlensystem von Bad Deutsch-Altenburg. Wissenschaftliche Mitteilungen aus dem Niederösterreichischen Landesmuseum /417 10 (N.F. 417):391-441.

Schmidt, E. and Topál, G. 1971. Fledermäuse in Eulengewöllen aus Ungarn. Vertebrata Hungarica, 12:93-102.

Schreber, J.C.D.v. 1774. Die Säugethiere in Abbildungen nach der Natur mit Beschreibungen. Erster Theil. Der Mensch. Der Affe. Der Maki. Die Fledermaus. Walther, Erlangen.

Sevilla García, P. 1988. Estudio paeontoloógico de los Quiróperos del Cuaternario espanol. Paleontologia $i$ Evolució, 22:113-233.

Sevilla, P., Esteban-Aenlle, J., and Lopez-Martínez, N. 1991. Interpretacion de los cambios morfologicos observados en tres poblaciones sucesivas de Mimomys medasensis de Casablanca (Castellon) en funcion de heterocronias del desarrollo. Revista Espanola de Paleontologia, 6:20-24.

Shimelmitz, R., Barkai, R., and Gopher, A. 2011. Systematic blade production at late Lower Paleolithic (400-200 kyr) Qesem Cave, Israel. Journal of Human Evolution, 61:458-479.

Sigé, B. 1974. Presence d'un Megaderma (Mammalia, Chiroptera) dans le Pléistocène inférieur à Sète (Hérault). Géologie Méditerrannéenne, 1:97-104.

Sigé, B. and Aguilar, J.-P. 1987. L'extension stratigraphique des Mégachiroptères dans le Miocène d'Europe méridionnale. Comptes Rendus de l'Académie des Sciences de Paris, 304:469-474.

Sigé, B., Crochet, J.-Y., Sudre, J., and Escarguel, G. 1997. Nouveaux sites d'âges variés dans les remplissages karstiques du Miocène inférieur de Bouzigues (Hérault, Sud de la France) - Partie I: sites et faunes 1 (Insectivores, Chiroptères, Artiodactyles). Geobios 10 (suppl 1):477-483.

Šindelář, J. 2012. Drobní savci v potravě sovy pálené ve východním Středomoři [Small mammals in diet of barn owl in the Eastern Mediterranean]. Unpublished MA thesis (in Czech), Charles University, Praha.

Smith, K.T., Maul, L.C., Barkai, R., and Gopher, A. 2013. To catch a chameleon, or actualism vs. natural history in the taphonomy of the microvertebrate fraction at Qesem Cave, Israel. Journal of Archaeological Science 40: 3326-3339.

Sommer, R., Niederle, M., Labes, R., and Zoller, H. 2009. Bat predation by the barn owl Tyto alba in a hibernation site of bats. Folia Zoologica, 58:98-103.
Špoutil, F. 2003. Geografická proměnlivost vrápencovitých: sympatrický posun, paralelismus nebo divergence? [Geographic variation in rhinolophid bats: characater displacement, paralellism or divergence?]. Unpublished MSc thesis [in Czech], University of South Bohemia, České Budějovice.

Šrámek, J. 2010. Populační a geografická proměnlivost létavců (Miniopterus) v západní Palearktidě [Population and Geographical Variation in Bent-winged Bats (Miniopterus) of western Palaearctic]. Unpublished MA thesis [in Czech], Charles University, Praha.

Šrámek, J., Gvoždík, V., and Benda, P. 2013. Hidden diversity in bent-winged bats (Chiroptera: Miniopteridae) of the Western Palaearctic and adjacent regions: implications for taxonomy. Zoological Journal of the Linnean Society, 167:165-190.

Steiner, H. 1961. Beiträge zur Nahrungsökologie von Eulen der Wiener Umgebung. Egretta 4:1-19.

Stiner, M.C., Gopher, A., and Barkai, R. 2009. Cooperative hunting and meat sharing 400-200 kya at Qesem Cave, Israel. Proceedings of the National Academy of Sciences U.S.A., 106:13207-13212.

Stiner, M.C., Gopher, A., and Barkai, R. 2011. Hearthside socioeconomics, hunting and paleoecology during the late Lower Paleolithic at Qesem Cave, Israel. Journal of Human Evolution, 60:213-233.

Storch, G. 1974. Quartäre Fledermaus-Faunen von der Insel Malta. Senckenbergiana Lethaea, 55:407-434.

Tata, C. and Kotsakis, T. 2005. Italian fossil Chiropteran assemblages: a preliminary report. Geo. Alp, 2:5360.

Tchernov, E. 1984. The Fauna of Sefunim Cave, Mt. Carmel, p. 401-419. In Ronen, A. (ed.), Sefunim Prehistoric Sites. Mount Carmel, Israel. BAR International Series 230 (II).

Tchernov, E. 1992. Eurasian-African biotic exchanges through the Levantive corridor during the Neogene and Quaternary. Courier Forschungsinstitut Senckenberg, 153:103-123.

Temple, H. and Cuttelod, A. 2009. The status and distribution of Mediterranean mammals. IUCN, Gland, Switzerland and Cambridge.

Thomas, O. 1907. On mammals from northern Persia. The Annals and Magazine of Natural History, seventh series, 20:196-202.

Tomes, R.F. 1857. Description of four undescribed species of bats. Proceedings of the Zoological Society, 1857:50-54.

Topál, G. 1974. The First Record of Megaderma in Hungary (Pliocene Sediments of Osztramos Locality 10). Vertebrata Hungarica, 15:95-104.

Vargas, J., Landaeta, C., and Simonetti, J.A. 2002. Bats as Prey of Barn Owls (Tyto alba) in a Tropical Savanna in Bolivia. Journal of Raptor Research, 36:146-148.

Woloszyn, B.W. 1987. Pliocene and Pleistocene Bats of Poland. Acta palaeontologia Polonica, 32:207-325. 
Zapfe, H. 1950. Die Fauna der miozänen Spaltenfüllung von Neudorf an der March (Č.S.R.). Chiroptera. Sitzungsberichte der österreichischen Akademie der Wissenschaften, mathematisch-naturwissenschaftliche Klasse, Abt. I, 159:51-64. 